\title{
UTILIZATION OF MUSHROOM POWDER FOR SUBSTITUTING DRIED SKIMMILK IN THE MANUFACTURE OF PROCESSED CHEESE SPREAD
}

\author{
FAYED, A. E. ${ }^{1}$, AZZA M. FARAHAT ${ }^{1}$ AND RAGIA O. MOHAMED ${ }^{2}$
}

1. Food Science Department, Faculty of Agriculture, Ain Shams University, Cairo

2. Food Technology Res. Inst., ARC, Giza

(Manuscript received 30 March 2009)

\begin{abstract}
The utilization of mushroom powder (MP) in substitution of skimmilk powder (SMP) in the manufacture of processed cheese spread (PCS)was the aim of this study.

The basic blend of PCS (control) was planned to contain 31\% dry matter (DM) and 25\% Fat/DM using mature Ras cheese and skimmilk powder (SMP) as additional source of milk solids not fat. SMP was substituted on the dry basis with MP at the levels of nil (the control), 2.5, 5.0 and $10.0 \%$. Melting salt $\left(\mathrm{S}_{9}\right.$ special) was added at the level of $4 \%$. The $\mathrm{pH}$ value of all blends was adjusted to 5.8. Level of $0.5 \%$ of $\mathrm{JOHA}^{\circledR} \mathrm{HBS}$ was added as preservative agent. The cooking was carried out at $85^{\circ} \mathrm{C}$ for $7 \mathrm{~min}$. with stirring velocity of 120-140 r.p.m. Thereafter, the resultant cheese spreads were filled into glass jars.

The results indicated that, although DM, fat/DM and ash/DM contents of PRCS were not influenced by adding MP, the total nitrogen (TN)/ DM content tended significantly to reduce when the level of SMP substitution with MP exceeded $5 \%$. The soluble nitrogen (SN)/TN content of all treatments of PRCS was higher even than that of the mature Ras cheese itself, from which was made, and decreased significantly as the portion of PM instead of SMP increased. The gradual substitution of SMP with MP in PCS making was associated with proportional increment in the fibers/DM content and decrement in the titratable acidity \%, in spite of the stability of $\mathrm{pH}$ value at 5.8. Hardness, cohesiveness, gumminess and chewiness exhibited proportionally higher values, while, springiness property behaved opposite trends as the MP was used instead of SMP in PCS recipes. Whether, the proportional replacement of SMP with MP or the prolonging of cold storage period was associated with gradual increase in the firmness (as indicated inversely from the penetration value) as well as in the oil separation index and decrease in the meltability \% of PRCS. The use of MP instead of SMP did not lead to any significant differences in the score of all organoleptic attributes of PCS. Moreover, the mushroom flavour was accepted and favorably preferred in PCS and improved the stability of sensory quality of PCS along the cold storage period, especially when the substitution level of SMP with MP was more than $2.5 \%$.

The substitution of SMP with MP up to $10 \%$ in PCS manufacture could be recommended.
\end{abstract}




\section{INTRODUCTION}

Processed cheeses are among cheese verities appreciated by consumers, whereas, they are considered the main daily sandwich filling food for school children or even for adults. The Egyptian dairy industry produce about 130.000 ton per year (CFI, 200V). Processed cheese is made by blending natural cheeses of different ages, degrees of maturity and sources, adding water, colouring agents and emulsifying salts and then heating and agitating until a homogenous mixture is produced. The naturally matured cheese containing partially hydrolyzed casein as well as flavouring source (maximum $20 \%$ of total blend protein). The blend contains fresh and moderate cheese curd as a source of intact casein (minimum $50 \%$ of total protein for spreadable type and $70 \%$ of block one).The final product has a consistency suitable for packaging, and can be stored at or near room temperature for long periods. (Meyer, 1973, Thomas, 1977, Berger et al, 1989, Caric \& Kalab, 1993, Fox et al, 2000, Abd El-Salam et al, 2005 and Mahran et al, 2007).

Foods and flavourings can be added to processed cheese to obtain a particular flavour, to enhance or modify its flavour, or to make the cheese more attractive. They include sausages ,meat ,ham ,salami ,salmon ,wines ,fruit ,coffee or chocolate ,tomato ,celery ,parsley ,chives ,caraway seed and onions (Thomas, 1977). Mushroom was suggested in this study for its several benefits. Mushroom has long been valued as delicious and nutritional food in many countries. Mushroom is appreciated, not only for texture and flavour but also for their chemical and nutritional characteristics (Manzi et al, 1999 and Diyabalanage, 2008). On a dry weight basis, they are considered to be good sources of digestible proteins (10-40\%), carbohydrates (3-21\%) and dietary fibre (3-35\%). Mushroom contains all the essential amino acids. Essential amino acid content is $34-39 \%$. The chemical score being $28-29$, which is low as compared with whole egg protein. The sulfur containing amino acids, cysteine and methionine are limiting amino acids in mushroom. However, Protein quality evaluation by NPR (net protein ratio), NPU (net protein utilization) and TDP (true digestibility of protein), showed that the mushroom is comparatively much lower than casein in all the parameters examined (Breene, 1990, Chang, 1991 and Longvah\& Deosthale, 1998).

Although mushroom contains all the main classes of lipids, including free fatty acids, mono-, di- and tri-glycerides, sterol esters and phospholipids, their levels are 2$8 \%$ (on dry weight basis). Oleic and linoleic acids accounted for $72-77 \%$ of the total fat in mushroom (Longvah\& Deosthale, 1998). The calorific value of most mushrooms is also low. Mushroom is excellent source of thiamine (vitamin $B_{1}$ ), riboflavin (vitamin $B_{2}$ ), nicotinic acid (vitamin $B_{3}$ ), biotin and ascorbic acid (vitamin $C$ ). Edible mushroom in cooked or other processed forms is suitable for diabetic and heart patients. 
Mushroom is not only source of nutrients but has also been reported as therapeutic food, useful in preventing diseases such as hypertension, hypercholesterolemia and cancer, whereas it contains interesting functional components such as $\beta$-glucans at concentration ranging from 0.21 to $0.53 \mathrm{~g} / 100 \mathrm{~g}$ on a dry basis (Bobek et al, 1995, Bobek \& Galbavy, 1999, Manzi \& Pizzoferrato, 2000 and Mallavadhani, 2006). The antitumor activities are attributed to stimulation of the cell-mediated immune response. Activated macrophages, natural killer cells, cytotoxic $T$ cells and their secretory products, such as tumor necrosis factor, reactive nitrogen and oxygen intermediates, and interleukins have been reported to be involved in immunomodulatory responses (Wang et al, 1995). Some isolated and identified compounds, originating from mushrooms, show other quite significant medical properties, other than immunomodulatory activity, such as cardiovascular, liver protective, anti-fibrotic, anti-inflammatory, anti-diabetic, anti-viral and antimicrobial activities (Gunde-Cimerman, 1999, Ooi \& Liu, 1999, Ooi, 2000, Wasser \& Weis, 1999a and 1999b).

With that in view, the present research was aimed to study the utilization of mushroom powder for substituting skimmilk powder in the manufacture of processed cheese spread taking in consideration maintaining the PCS attributes and sensory acceptance.

\section{MATERIALS AND METHODS}

\section{Materials}

Skim milk powder made by Lactex in Poland, mature Ras cheese made by Misr Milk \& Food Co., cooking salt produced by El-Nasr Saline's Co., JOHA ${ }^{\circledR} \mathrm{S}_{9}$ special, as melting or emulsifying salt, and $\mathrm{JOHA}^{\circledR} \mathrm{HBS}$, as preservative agent, made by JOHA BK Giulini Ladenburg Corporation, $\mathrm{GmbH}$, Germany, were obtained from the local market at Cairo. Freshly common (button) mushroom (Agaricus bisporus) fruiting body was obtained from Research \& Production Unit of Mushroom, Faculty of Agriculture, Ain Shams University at Cairo. The composition of dairy ingredients used is presented in Table (1) . 
Table 1. Gross composition of ingredients used for making processed cheese spread

\begin{tabular}{|c|c|c|c|}
\hline \multirow{2}{*}{ Component \% } & \multicolumn{3}{|c|}{ Ingredient } \\
\cline { 2 - 4 } & Ras cheese & SMP & MP \\
\hline Dry matter (DM) & 73.10 & 95.50 & 95.85 \\
\hline Total nitrogen (TN)/ DM & 6.297 & 5.760 & 5.204 \\
\hline Fat/DM & 45.91 & 1.05 & 1.90 \\
\hline Carbohydrate*/ DM & - & 55.0 & 48.8 \\
\hline Fibers/ DM & - & - & 8.10 \\
\hline Ash/ DM & 8.89 & 7.20 & 8.00 \\
\hline Soluble nitrogen/TN & 30.70 & 12.57 & 7.24 \\
\hline
\end{tabular}

SMP: Skim milk powder

MP: Mushroom powder

* Calculated by difference

\section{Experimental procedures}

\section{Drying and powdering of mushroom fruiting body}

Mushroom fruiting body was cleaned, cut into slices, dried in an oven at $65^{\circ} \mathrm{C}$ for 48 h. as described by Buwjoom et al (2004), and finely powdered. Composition of the resultant powdered mushroom is present in Table (1).

\section{Preparation of PCS with ascending mushroom content}

The basic blend of processed cheese spread (control) was planned to contain $31 \%$ dry matter (DM) and 25\% Fat/DM according to EOSQ (2005). Mature Ras cheese and SMP as additional source for milk solids not fat were used for the experimental PCS at suitable level as recommended by Meyer (1973). SMP was substituted on the dry basis with MP at the levels of nil (the control), 2.5, 5.0 and 10.0\%. Melting salt ( $\mathrm{S}_{9}$ special ) was added at the level of $4 \%$ as permitted by EOSQ ( 2005 ). Furthermore, the $\mathrm{pH}$ value of all blends was adjusted to 5.8 as recommended by Meyer (1973) using $10 \%$ citric acid or $\mathrm{NaHCO}_{3}$ solutions. A level of $0.5 \%$ of $\mathrm{JOHA}{ }^{\circledR} \mathrm{HBS}$ was added as preservative agent as recommended by BK Giulini (2007). The preparations of the initial ingredients and cooking procedure were carried out as described by Meyer (1973) at $85^{\circ} \mathrm{C}$ for $7 \mathrm{~min}$. using a double jacket pan with a batch capacity of $2.0 \mathrm{~kg}$ and stirring velocity of 120-140 r.p.m. Thereafter, the resultant cheese spreads were filled into glass jars $(200 \mathrm{~g})$, airtightly closed and cold stored for analysis. Three replicates were carried out for each PCS treatment. 
Table 2. The blend formulas $(\mathrm{kg} / 100 \mathrm{~kg}$ ) for processed cheese spread as affected by the substitution level of skim milk powder (SMP) with mushroom powder (MP).

\begin{tabular}{|c|c|c|c|c|}
\hline \multirow{2}{*}{ Ingredient } & \multicolumn{4}{|c|}{ Level (\%) of SMP substitution with MP } \\
\cline { 2 - 5 } & Nil (control) & 2.5 & 5.0 & 10.0 \\
\hline $\begin{array}{c}\text { Mature Ras } \\
\text { cheese (73\% } \\
\text { DM) }\end{array}$ & 24.20 & 24.20 & 24.20 & 24.20 \\
\hline SMP (96\% DM) & 9.17 & 8.94 & 8.71 & 8.25 \\
\hline PM (96\% DM) & 0.00 & 0.23 & 0.46 & 0.92 \\
\hline JOHA ${ }^{\circledR} \mathrm{S}_{9}$ Special & 4.00 & 4.00 & 4.00 & 4.00 \\
\hline JOHA ${ }^{\circledR} \mathrm{HBS}$ & 0.50 & 0.50 & 0.50 & 0.50 \\
\hline Water & 62.13 & 62.13 & 62.13 & 62.13 \\
\hline
\end{tabular}

\section{Analytical methods}

Contents of dry matter (DM), total nitrogen (TN), water soluble nitrogen (SN), fat and ash were determined as reported by AOAC (2007). The $\mathrm{pH}$ value was measured electrometrically using Lab. pH meter with a glass electrode, Hanna model 8417. Texture profile of PCS was measured at $23^{\circ} \mathrm{C}$ as described by Bourne (1982) using an Instron Universal Testing Machine model 1195, Stable Micro System (SMS) Ltd., Godalming, UK, loaded with Dimension Software SMS Program. Likewise, Penetration value was measured as in Bourne (1982). Oil separation index was determined according to Thomas (1973). Meltability was measured using the meltability test apparatus as described by Gunasekaran \& Ak (2003).

Organoleptic properties of processed cheese spread were evaluated according to scheme of Meyer (1973). The obtained data were statistically analyzed according to statistical analyses system user's guide (SAS, 1998).

\section{RESULTS AND DISCUSSION}

\section{Compositional and chemical properties}

Data displaying in Table (3) reveal that, the previous adjustment of the contents of dry matter at $31 \%$ as well as the fat/ DM at $25 \%$ of the recipes of PCS led to gain non-significant differences in both criteria among all treatments. Likewise, the ash/ DM content of PCS showed non significant differences between samples as a function of the partial replacement of SMP with MP. Whereas, the TN/ DM content tended significantly to reduce when the level of SMP substitution with MP exceeded $5 \%$ 
(Table, 3). That could be ascribed to the relatively lower TN/ DM \% of MP versus that of SMP (Table, 1).

Table 3. Chemical properties of processed cheese spread as affected by the substitution level of skim milk powder (SMP) with mushroom powder (MP).

\begin{tabular}{|c|c|c|c|c|}
\hline \multirow{2}{*}{ Property } & \multicolumn{4}{|c|}{ Level (\%) of SMP substitution with MP } \\
\cline { 2 - 5 } & Nil (control) & 2.5 & 5.0 & 10.0 \\
\hline Dry matter (DM) \% & $31.03^{\mathrm{a}}$ & $30.99^{\mathrm{a}}$ & $30.95^{\mathrm{a}}$ & $30.96^{\mathrm{a}}$ \\
\hline Fat/DM\% & $25.00^{\mathrm{a}}$ & $25.02^{\mathrm{a}}$ & $25.06^{\mathrm{a}}$ & $25.01^{\mathrm{a}}$ \\
\hline $\begin{array}{c}\text { Total nitrogen } \\
\text { (TN)/DM\% }\end{array}$ & $5.737^{\mathrm{a}}$ & $5.734^{\mathrm{a}}$ & $5.731^{\mathrm{a}}$ & $5.721^{\mathrm{b}}$ \\
\hline Fibers/DM\% & $0.000^{\mathrm{d}}$ & $0.058^{\mathrm{c}}$ & $0.115^{\mathrm{b}}$ & $0.231^{\mathrm{a}}$ \\
\hline Ash/DM\% & $20.11^{\mathrm{a}}$ & $20.11^{\mathrm{a}}$ & $20.12^{\mathrm{a}}$ & $20.12^{\mathrm{a}}$ \\
\hline $\begin{array}{c}\text { Soluble } \\
\text { nitrogen/TN \% }\end{array}$ & $66.309^{\mathrm{a}}$ & $63.357^{\mathrm{b}}$ & $60.773^{\mathrm{c}}$ & $57.585^{\mathrm{c}}$ \\
\hline $\begin{array}{c}\text { Titratable acidity \% } \\
\text { pH value }\end{array}$ & $\begin{array}{c}2.65^{\mathrm{a}} \\
5.8^{\mathrm{a}}\end{array}$ & $2.55^{\mathrm{b}} 5.8^{\mathrm{a}}$ & $2.50^{\mathrm{b}} 5.8^{\mathrm{a}}$ & $2.40^{\mathrm{c}}$ \\
\hline
\end{tabular}

The means with the same letter did not significantly differ $(P>0.05)$.

Moreover, it is worthy to mention that, the SN/TN content of PCS was higher even than that of the mature Ras cheese itself, from which was made. This phenomena may be attributed to the action of the melting salt added, which made to dissociate the protein-protein interactions. These findings agree with those found by Abdel-Hamid et al (2000). Among treatments, the SN/TN content of PCS decreased significantly as the portion of MP instead of SMP increased. This may be happen because of the relatively low SN/TN content of MP versus that of SMP (Table, 1 ).

As well known, the dairy ingredients used never contain any dietary fibers, therefore MP is considered as dietary fiber source and consequently the gradual substitution of SMP with MP was associated with significantly proportional increase in the fibers/DM content of PCS.

Furthermore, data given in Table (3) show that, although the designed $\mathrm{pH}$ value, at which PCS recipes were cooked, remained unchanged at 5.8. The titratable acidity \% of resultant PCS seemed a significantly proportional reduction as the portion of MP instead of SMP raised. This phenomenon may be due to the buffering compounds in the PCS such as proteins and the added melting salts.

\section{Textural profile}

Regarding the texture parameters of PCS, data illustrated in Table (4) indicate that, except of the springiness criterion, other texture parameters, namely hardness, 
cohesiveness, gumminess and chewiness exhibited significantly proportionally higher values, i.e. the texture of PCS becomes harder, more gummy and chewy as the MP was used instead of SMP in their recipes. These observations may be explained with regard to the SN/TN content of PCS. However, the hardness, cohesiveness, gumminess and chewiness followed a reverse direction trend with SN level. Similar findings were reported by Pollard et al (2003) and El-Zeini et al (2007).

However, springiness property of PCS behaved opposite trends towards the SN/TN content.

Table 4. Textural profile of processed cheese spread as affected by the substitution level of skim milk powder (SMP) with mushroom powder (MP).

\begin{tabular}{|c|c|c|c|c|}
\hline \multirow{2}{*}{ Property } & \multicolumn{4}{|c|}{ Level (\%) of SMP substitution with MP } \\
\cline { 2 - 5 } & Nil (control) & 2.5 & 5.0 & 10.0 \\
\hline Springiness (mm) & $19.99^{\mathrm{a}}$ & $19.81^{\mathrm{a}}$ & $19.13^{\mathrm{ab}}$ & $18.28^{\mathrm{b}}$ \\
\hline Hardness (N) & $5.452^{\mathrm{d}}$ & $7.954^{\mathrm{c}}$ & $10.958^{\mathrm{b}}$ & $12.959^{\mathrm{a}}$ \\
\hline Cohesiveness (-) & $37.376^{\mathrm{d}}$ & $65.541^{\mathrm{c}}$ & $71.927^{\mathrm{b}}$ & $81.305^{\mathrm{a}}$ \\
\hline Gumminess (N) & $203.77^{\mathrm{d}}$ & $521.31^{\mathrm{c}}$ & $788.18^{\mathrm{b}}$ & $1052.56^{\mathrm{a}}$ \\
\hline Chewiness (N/m) & $4.073^{\mathrm{d}}$ & $10.327^{\mathrm{c}}$ & $15.078^{\mathrm{b}}$ & $19.241^{\mathrm{a}}$ \\
\hline
\end{tabular}

The means with the same letter at any position did not significantly differ $(P>0.05)$.

$\mathrm{N}$ : Newton

m: metre

$\mathrm{mm}$ : millimetre

\section{Physical properties}

Concerning the common physical properties, namely, the firmness, oil separation index and meltability \% of PCS as a function of the level of SMP substitution with MP and/or the cold storage period for 3 months, data of Table (5) demonstrate that, like what happened with the hardness, the firmness of PCS as indicated inversely from the penetration values was significantly strengthened as the SMP was substituted with MP. Moreover, gradual increases in the firmness of PCS were recorded in relation to the prolonging of cold storage period. This phenomenon may be attributed to the interaction of the melting salts with the protein as well as the decrease in $\mathrm{pH}$ values during storage caused by the changes in the form of melting salts. The results agree with the finding of Tamime et al (1990), Younis et al (1991) and Gab-Allah (2004).

Regarding the oil separation index of PCS data indicate that, both the proportional replacement of SMP with MP and the prolonging of cold storage period was associated with gradual weakness in the fat emulsion, i.e. increase in the oil separation. This means that, the emulsion capacity of MP protein was lower than that of SMP protein. Likewise, the increment in $\mathrm{SN}$ content and/or the reduction in the $\mathrm{pH}$ 
value of PCS that occurred during cold storage period may result in lower degree of lipid emulsification and higher fat leakage. Whereas, the lower $\mathrm{pH}$ may cause an adverse effect on the protein bonds and give a loose protein network, which lead to demulsify the fat and consequently make it easy to release. Shimp (1985) confirmed that, as the cheese pH brought closer to 5.0, the proteins-protein bounds weaken and the fat start to demulsify. Similar findings were reported by Abd El-Salam et al (1996 and 2005), Abd El-Hamid et al (2000), Awad et al (2003) and Gab-Alla (2004).

Table 5. Physical properties of processed Ras cheese spread during cold storage at $5^{\circ} \mathrm{C}$ for 3 months as affected by the substitution level of skim milk powder (SMP) with mushroom powder (MP).

\begin{tabular}{|c|c|c|c|c|c|}
\hline \multirow[b]{2}{*}{ Property } & \multirow{2}{*}{$\begin{array}{l}\text { Storage } \\
\text { period } \\
\text { (month) }\end{array}$} & \multicolumn{4}{|c|}{ Level $(\%)$ of SMP substitution with MP } \\
\hline & & Nil (control) & 2.5 & 5.0 & 10.0 \\
\hline \multirow{3}{*}{ Penetration (mm) } & Fresh & $30.1^{\mathrm{a}, \mathrm{a}}$ & $28.9^{b, a}$ & $27.8^{c, a}$ & $26.5^{\mathrm{d}, \mathrm{a}}$ \\
\hline & 1 & $28.0^{a, b}$ & $27.5^{\mathrm{b}, \mathrm{b}}$ & $26.4^{c, b}$ & $25.0^{\mathrm{d}, \mathrm{b}}$ \\
\hline & 3 & $26.6^{\mathrm{a}, \mathrm{c}}$ & $25.4^{\mathrm{b}, \mathrm{c}}$ & $25.0^{\mathrm{b}, \mathrm{c}}$ & $24.6^{c, b}$ \\
\hline \multirow{3}{*}{ Oil separation index } & Fresh & $12.5^{d, c}$ & $16.2^{c, b}$ & $20.1^{b, b}$ & $22.3^{a, b}$ \\
\hline & 1 & $13.2^{\mathrm{d}, \mathrm{b}}$ & $16.9^{c, a}$ & $20.4^{\mathrm{b}, \mathrm{ab}}$ & $22.8^{\mathrm{a}, \mathrm{ab}}$ \\
\hline & 3 & $14.0^{\mathrm{d}, \mathrm{a}}$ & $17.1^{\mathrm{c}, \mathrm{a}}$ & $20.8^{\mathrm{b}, \mathrm{a}}$ & $23.4^{\mathrm{a}, \mathrm{a}}$ \\
\hline \multirow{3}{*}{ Meltability \% } & Fresh & $115^{\mathrm{a}, \mathrm{a}}$ & $105^{\mathrm{b}, \mathrm{a}}$ & $80^{c, a}$ & $60^{\mathrm{d}, \mathrm{a}}$ \\
\hline & 1 & $113^{\mathrm{a}, \mathrm{ab}}$ & $102^{\mathrm{b}, \mathrm{ab}}$ & $78^{\mathrm{c}, \mathrm{a}}$ & $58^{\mathrm{d}, \mathrm{a}}$ \\
\hline & 3 & $109^{a, b}$ & $98^{\mathrm{b}, \mathrm{b}}$ & $76^{c, a}$ & $55^{\mathrm{d}, \mathrm{b}}$ \\
\hline
\end{tabular}

The letters before comma possess the factor of the level of SMP substitution with MP. While those after comma possess the factor of the cold storage period. The means with the same letter at any position did not significantly differ $(P>0.05)$.

Opposite to the oil separation index, the meltability \% of PCS was lowered whether as the SMP was replaced with MP or/ and as the cold storage period progressed. Shimp (1985) mentioned that, as the cheese pH was brought closer to 5.0 , the texture could become crumbly because the protein-protein bounds weaken. Cavalier-Salou and Cheftel (1991) reported that, the melting ability was correlated to high $\mathrm{pH}$, soft texture and high degree of casein dissociation.

\section{Organoleptic quality}

The sensory scoring (Table, 6 ) indicates that, the use of MP instead of SMP did not lead to any significant differences in the score of all organoleptic attributes judged in PCS. Moreover, the mushroom flavour was accepted and favorably preferred in PCS. The overall panelist scores confirm the previous observations regarding the different 
organoleptic criteria. Furthermore, mushroom improved the PCS ability to keep its sensory quality along the cold storage period, when the substitution level of SMP with MP was more than $2.5 \%$.

Table 6. Organoleptic scores of processed Ras cheese spread during cold storage at $5^{\circ} \mathrm{C}$ for 3 months as affected by the substitution level of skim milk powder (SMP) with mushroom powder (MP).

\begin{tabular}{|c|c|c|c|c|c|}
\hline \multirow{2}{*}{ Sensory attribute } & \multirow{2}{*}{$\begin{array}{c}\text { Storage period } \\
\text { (month) }\end{array}$} & \multicolumn{4}{|c|}{ Level (\%) of SMP substitution with MP } \\
\hline & & Nil (control) & 2.5 & 5.0 & 10.0 \\
\hline \multirow{3}{*}{ Appearance (20) } & Fresh & $20^{\mathrm{a}, \mathrm{a}}$ & $20^{\mathrm{a}, \mathrm{a}}$ & $20^{\mathrm{a}, \mathrm{a}}$ & $20^{a, a}$ \\
\hline & 1 & $20^{\mathrm{a}, \mathrm{a}}$ & $20^{\mathrm{a}, \mathrm{a}}$ & $20^{\mathrm{a}, \mathrm{a}}$ & $20^{\mathrm{a}, \mathrm{a}}$ \\
\hline & 3 & $20^{\mathrm{a}, \mathrm{a}}$ & $20^{a, a}$ & $20^{a, a}$ & $20^{\mathrm{a}, \mathrm{a}}$ \\
\hline \multirow{3}{*}{ Aroma \& Flavour (40) } & Fresh & $39^{a, a}$ & $39^{a, a}$ & $39^{a, a}$ & $40^{\mathrm{a}, \mathrm{a}}$ \\
\hline & 1 & $38^{\mathrm{a}, \mathrm{a}}$ & $38^{\mathrm{a}, \mathrm{a}}$ & $38^{\mathrm{a}, \mathrm{a}}$ & $39^{\mathrm{a}, \mathrm{a}}$ \\
\hline & 3 & $38^{\mathrm{a}, \mathrm{a}}$ & $38^{\mathrm{a}, \mathrm{a}}$ & $38^{a, a}$ & $38^{\mathrm{a}, \mathrm{a}}$ \\
\hline \multirow{3}{*}{ Body \& Texture (40) } & Fresh & $39^{a, a}$ & $39^{a, a}$ & $39^{a, a}$ & $39^{\mathrm{a}, \mathrm{a}}$ \\
\hline & 1 & $38^{\mathrm{a}, \mathrm{a}}$ & $38^{\mathrm{a}, \mathrm{a}}$ & $38^{\mathrm{a}, \mathrm{a}}$ & $39^{a, a}$ \\
\hline & 3 & $36^{\mathrm{b}, \mathrm{b}}$ & $37^{\mathrm{a}, \mathrm{a}}$ & $38^{\mathrm{a}, \mathrm{a}}$ & $39^{\mathrm{a}, \mathrm{a}}$ \\
\hline \multirow{3}{*}{ Total score (100) } & Fresh & $98^{\mathrm{a}, \mathrm{a}}$ & $98^{\mathrm{a}, \mathrm{a}}$ & $98^{\mathrm{a}, \mathrm{a}}$ & $99^{\mathrm{a}, \mathrm{a}}$ \\
\hline & 1 & $96^{\mathrm{a}, \mathrm{a}}$ & $96^{\mathrm{a}, \mathrm{a}}$ & $96^{\mathrm{a}, \mathrm{a}}$ & $98^{\mathrm{a}, \mathrm{a}}$ \\
\hline & 3 & $94^{\mathrm{b}, \mathrm{a}}$ & $95^{\mathrm{b}, \mathrm{a}}$ & $96^{\mathrm{a}, \mathrm{a}}$ & $97^{\mathrm{a}, \mathrm{a}}$ \\
\hline
\end{tabular}

The letters before comma possess the factor of the level of SMP substitution with MP. While those after comma possess the factor of the cold storage period. The means with the same letter at any position did not significantly differ $(P>0.05)$.

As a conclusion, the foregoing results led to conclude that, PCS could be successfully made with MP as substitute for SMP up to $10 \%$ level.

\section{REFERENCES}

1. Abdel-Hamid, L. B., S. A. El-Shabrawy, R. A. Awad and R. K. Singh. 2000. Chemical properties of Ras cheese spreads as affected by emulsifying salt mixtures. J. Food Processing Preservation, 24: 191-208.

2. Abd-El-Salam, M. H., S. El-Shibiny and N. S. Ahmed. 2005. Studies on processed cheese spreads in Egypt. A review. Egypt. J. Dairy Sci., 33: 129-141.

3. Abd-El-Salam, M. H., A. F. Al-Khamy, G. A. El-Garawany, A. Hamed and A. Khader. 1996. Composition and reological properties of processed cheese spread as affected by the level of added whey protein concentrates and emulsifing salt. Egypt. J. Dairy Sci., 24: 309-322. 
4. AOAC. 2007. Association of Official Analytical Chemists. Official Method of Analysis. (18 ${ }^{\text {th }}$ Ed.), pp.802-850.Benjamin Franklin Stationary Washington, D.C., USA.

5. Berger, W., H. Klostermeyer, K. Merkenicl and G. Uhlmann. 1989. In: Processed Cheese Manufacture. A Joha ${ }^{\circledR}$ Guide BK Ladenburg $\mathrm{GmbH}$, Gesellschaft fuer chemische Erzeugnisse, Ladenburg, Germany.

6. BK Giulini. 2007. Microbiological properties of the raw material for processing. In : Business Line Dairy, Process Cheese Manufature, short guide, pp. 10-11. BK Giulini $\mathrm{GmbH}$, Ladenburg, Germany.

7. Bobek, P. and S. Galbavy. 1999. Hypocholesterolemic and antiatherogenic effect of oyster mushroom (Pleurotus ostreatus) in rabbit. Nahrung, 43: 339-342.

8. Bobek, P., L. Ozdyn and L. Kuniak. 1995. The effect of oyster (Pleurotus ostreatus) its ethanolic extracts and extraction residues on cholesterol levels in serum lipoproteins and liver of rat. Hypocholesterolemic and anti-atherogenic effect of oyster mushroom (Pleurotus ostreatus) in rabbit. Nahrung, 39: 98-99.

9. Bourne, M. C. (Ed.) 1982. Food Texture and Viscosity Concept and Measurement. pp. 544-546.Academic Press Inc., New York, USA.

10. Breene, W. 1990. Nutritional and medicinal value of speciality mushrooms. J. Food Prot., 53: 883-894.

11. Buwjoom, T., S. Tangtaweewipat, N. Thongwittaya and K. Yamauchi. 2004. Chemical composition nutrient digestibility and metabolizable energy of shiitake mushroom stalk meal. J. Poultry Sci., 41: 322-328.

12. Caric, M. and M. Kalab. 1993. Processed Cheese Products. In: Cheese Chemistry Physics, and Microbiology. PP 467-505. $2^{\text {nd }}$ Ed, ed by Fox, P. F., Major Cheese groups, Chapman Hall Ltd, London, UK.

13. Cavalier-Salou, C. and J. C. Cheftel. 1991. Emulsifying salts influence on characteristics of cheese analogs from calcium caseinate. J. Food Sci., 56: 15421547.

14. CFI. 2007. Chamber of Food Industries. Annual Report, Cairo.

15. Chang, S. T. 1991. Cultivated Mushrooms. Handbook of Applied Mycology. (Vol. 3, pp. 221-240). Marcel Dekker Bubl.New York, USA.

16. Chang, S. T. and P. G. Miles. 2004. Mushrooms: Cultivation, Nutritional Value, Medicinal Effect, and Environmental Impact. $2^{\text {nd }}$ Ed., pp. 27-52, CRC Press, USA.

17. Diyabalanage, T., V. Mulabagal, G. Mills, D. L. DeWitt and M. G. Nair. 2008. Health-beneficial qualities of the edible mushroom, Agrocybe aegerita. Food Chem., $108:$ : 97-102. 
18. El-Zeini, H. M., M. A. El-Aasser, S. M. K. Anis and E. A. H. Romeih. 2007. Influence of some processing treatments on chemical composition, rheological properties and micro-structure of cast UF-white soft cheese. Egypt. J. Dairy Sci., 35: 57-72.

19. EOSQ. 2005. Egyptian Orgnization for Standards and Quality. Processed cheese. Part 2: Spreadable processed cheese, Egyptian Standard (ES) 999/2005.

20. Fox,P. F., T. P. Guinee, T. M. Cogan and P. L. H. McSweeney (Eds). 2000. Fundamentals of Cheese Science. Pp 429-451. Aspen Publ., Inc., Gaithersburg, Maryland, USA.

21. Gab-Allah, R. H. 2004. Utilization Whey Derivatives in Some Dairy Products. pp. 22- 45. M. Sc. Thesis, Fac. Agric., Ain Shams Univ. Egypt.

22. Gunasekaran, S. and M. M. Ak (Eds). 2003. Cheese Rheology and Texture. pp. 299-375. CRC Press LLC, Washington, D.C., USA.

23. Gunde-Cimerman, N. 1999. Medicinal value of the genus pleurotus (Fr) P. Karst. (Agaricles S.R., Basidiomycetes). International J. Medicinal Mushrooms, 1, 69-70.

24. Longvah, T. and Y. G. Deosthale. 1998. Compositional and nutritional studies on edible wild mushroom from northeast India. Food Chem., 63: 331-334.

25. Mahran, G. A., A. E. Fayed, M. H. Youssef and M. S. Negm. 2007. Utilization of ultrafiltrated whey protein concentrate in the manufacture of reduced fat processed cheese spread. J. Biol. Chem. Environ. Sci., 2: 137-151.

26. Mallavadhani, U. V., A. V. S. Sudhakar, K. V. S. Satyanarayana, A. Mahapatra, W. $\mathrm{Li}$ and R. B. vanBreemen. 2006. Chemical and analytical screening of some edible mushrooms. Food Chem., 95: 58-64.

27. Manzi, P., L. Gambelli, S. Marconi, V. Vivanti and L. Pizzoferrato. 1999. Nutrients in edible mushrooms: an interspecies comparative study. Food Chem., 65: 477482.

28. Manzi, P. and L. Pizzoferrato. 2000. Beta-glucans in edible mushrooms. Food Chem., 68: 315-318.

29. Meyer, A. 1973. Processed Cheese Manufacture. pp. $30-276.1^{\text {st }}$ Ed. Food Trade Press. Ltd., London, UK.

30. Olson, N. F. and W. V. Price. 1958. A melting test for pasteurized process spreads. J. Dairy Sci., 41:999-1000.

31. Ooi, V. E. C. 2000. Medicinally Important Fungi. In Van Griensven (Ed.), Science and Cultivation of Edible Fungi (pp. 41-51). Rotterdam: Balkema.

32. Ooi, V. E. C. and F. Liu. 1999. A review of pharmacological activities of mushroom polysaccharides. Int.J. Medicinal Mushrooms, 1: 195-206. 
33. Pollard, A., F. Sherkat, M. G. Seuret and A. L. Halmos. 2003. Textural changes of natural Cheddar cheese during the maturation process. J. Food Sci., 68, 20112016.

34. Savello, P. A., C. A. Ernstrom and M. Kalab. 1989. Microstructure and meltability of model processed cheese made with rennet and acid casein. J. Dairy Sci. 72: 1-11

35. Thomas, M. A. 1973. The use of hard milk fat fraction in processed cheese. Aust. J. Dairy Technol., 28: 77-80.

36. Thomas, M. A. (Ed.) 1977. The Processed Cheese Industry. $1^{\text {st }}$. Ed., Series, Bull. (New South Wales. Dept. of Agric., D44). Joseph Vogele Co., Germany.

37. Wang, H. X., W. K. Liu, T. B. Ng, V. E. C. Ooi and S. T. Chang. 1995. Immunomodulatory and antitumor activities of polysaccharide-peptide complex from a mycelial culture of Txicholoma sp., a local edible mushroom. Life Sci., 57: 269-281.

38. Wasser, S. P. and A. L. Weis. 1999a. Medicinal properties of substances occurring in higher asidiomycete mushrooms: Current perspective. Int. J. Medicinal Mushrooms, 1: 31-62.

39. Wasser, S. P. and A. L. Weis. 1999b. Therapeutic properties of substances occurring in Higher basidiomycete mushrooms: a modern perspective. Critical Review of Immunology, 19: 65-96. 


\title{
الإستفادة من مسحوق عيش الغراب فى إستبدال اللبن الفرز المجفق فى صناعة مفرود الجبن المطبوخ
}

\author{
عاطف السيد فايد' عزة محمود فرحات' راجية عمر محمد \\ ا ـ ـ قسم علوم الأغذية- كلبة الزراعة- جامعة عين شعس - القاهة \\ r r معرد بحوث تكنولوجيا الأغذية- مركز البحوث الزراعية- الجبيزة
}

استهدفت الدراسة تجربة دمج عيش الغراب المجفف مع مفرودالجبن الراس المطبوخ لدراسة إلى أى

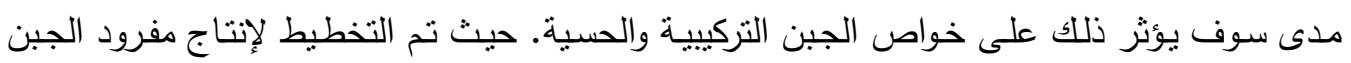

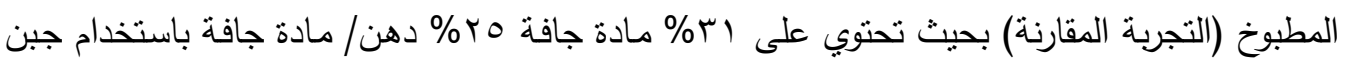
راس ناضـج ولبن فرز مجفف كمصدر إضـافى للجوامد اللبنيـة اللادهنية. ولتحقيق هدف الدراسـة تم

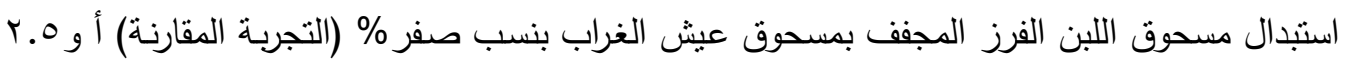

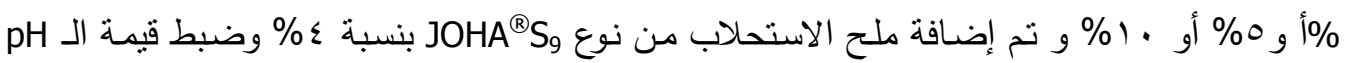

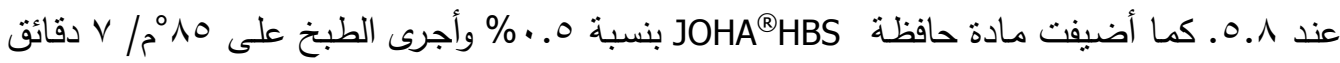

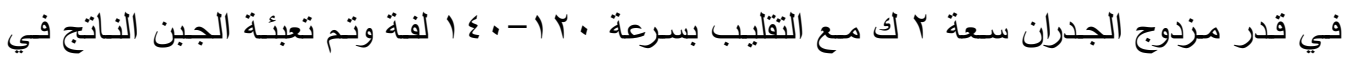

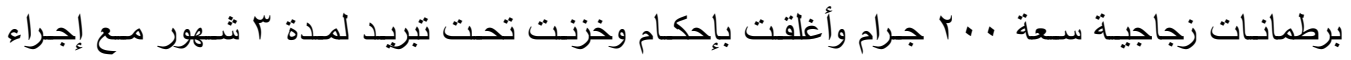
الفحوصات التركيبيةوالحسية دوريا خلال هذة الفترة. وقد أوضحت النتائج أنه بالرغم من أن نسب المادة الجافة و الدهن/ المادة الجافة والرماد/ المادة

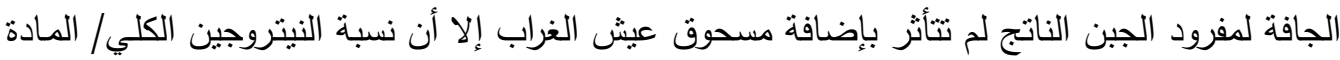
الجافة إتجهت نحو الإنخفاض بصورة معنويـة عند زيادة نسبة الاستبدال عن ه\%. وعلى العكس من إلن ذلك فإن نسبة النيتروجين الذائب/ النيتروجين الكلي لكل معاملات مفرود الجبن كانت أعلى حتى من

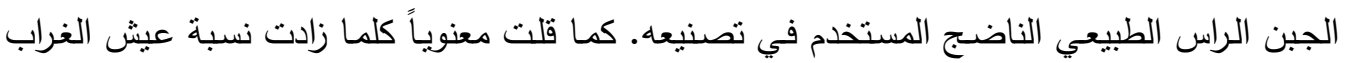
بدلاً من اللبن الفرز المجفف. ولقد ارتبط الاستبدال التدريجي لمسحوق اللبن الفرز المجفف بمسحوق فئه

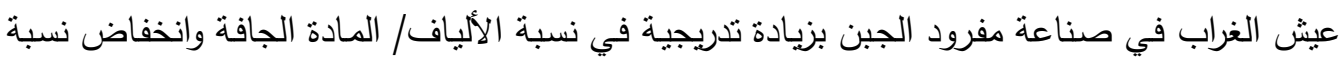

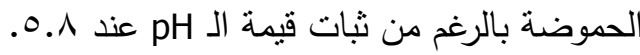
وفيما يختص بخواص التركيب البنائي لمفرود الجبن المطبوخ والتي تتـتمل على قيم الجمودة

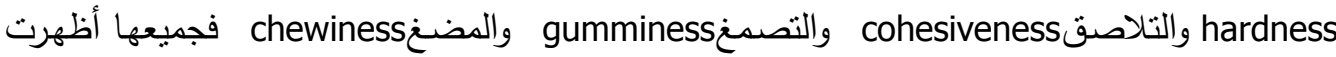
زيادة تدريجية مع زيادة نسبة الأستبدال بينما أظهرت صفة المطاطيةcosingness اتجاه معاكس. ولقد أرتبط الاستبدال التدريجي لمسحوق اللبن الفرز بمسحوق عبش الغرة الغراب أو إطالة مدة التخزين المبرد

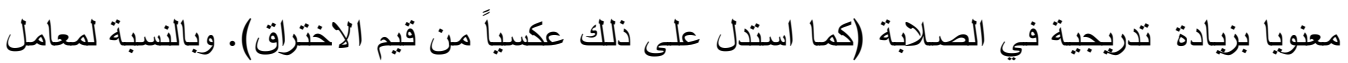
انفصال الزيت فقدأ زداد بينما انخفضت نسبة القابلية للانصهار في مفرود الجبن المطبوخ الناتج بزيادة نسبة الأستبدال وكذلك بإطالة مدة التخزين المبرد. وبالنسبة لنكهة الجبن المطبوخ المضاف إليه عيش لهن الغراب المجف فكانت مقبولة عند جيع فترات الفحص خلال التخزين المبرد لمدة آثهور وحتى عند مستوى • (\% استبدال لمسحوق اللبن الفرز. 